\title{
EWA BAL
}

iD https://orcid.org/0000-0002-2434-6108

Uniwersytet Jagielloński

ewa.bal@uj.edu.pl

\section{A CO, JEŚLI PRZESZł OŚĆ POWRÓCI? TŁUMACZENIE DAWNYCH TEKSTÓW DLA TEATRU JAKO PERFORMOWANIE RESZTEK}

\begin{abstract}
What if the Past Returns? Translating Old Theatre Texts as Performing Remains

The article is an attempt to transfer into the field of translation studies selected theories of performance and of performative strategies of establishing relations with the past. The author seeks to define the act of translating old theatrical texts - a fragmentary trace of the Italian dell'arte, a theatrical practice which is forgotten yet paradoxically still reproduced based on specific principles - as "performing remains". The term is borrowed from Rebecca Schneider, an American performance scholar who introduced it into contemporary humanities in her book Performing Remains. Art and War in Time of Theatrical Reenactment (2011) to describe the theatrical reconstructions of historical events and artistic transformations of historical performances. The tensions between the material and non-material traces of the past and the possibilities of their contemporary transformation in performative actions, as described by Schneider, provide a point of departure for reflecting on the act of translating as an epistemological tool for constructing knowledge about the past and, at the same time, for making the past present in a performative way.
\end{abstract}

Keywords: performing remains, situated knowledges, translation, performance, ephemerality, past, present

Słowa kluczowe: performowanie resztek, wiedze usytuowane, przekład, performans, efemeryczność, przeszłość, teraźniejszość 
Przygotowując niedawno projekt badawczo-wydawniczy dotyczący przekładu włoskich XVII-wiecznych scenariuszy komedii dell'arte na język polski, stanęłam przed szeregiem pytań metodologicznych dotyczących strategii tłumaczenia dawnych tekstów teatralnych. Podstawowa trudność wynikała bowiem z typologii tych tekstów oraz ustalenia ich relacji z dawną praktyką sceniczną. Korpus XVII-wiecznych tekstów pisanych dla włoskiego teatru określanego mianem komedii dell'arte często nazywa się scenariuszami, choć jest to określenie bardzo mylące i w dodatku zdominowane przez współczesne znaczenie terminu ,scenariusz” - czyli projekt przedstawienia filmowego, telewizyjnego lub teatralnego. W rzeczywistości, jeśli jakiekolwiek scenariusze komedii dell'arte ukazywały się XVII wieku drukiem, jak chociażby Teatro delle favole rappresentative Flaminia Scali z 1611 roku czy Le Théâtre Italien Evarista Gherardiego w 1694 roku, to raczej były to publikacje zaświadczające o przebiegu przestawień teatralnych a posteriori (czyli po wieloletnim eksploatowaniu ich na scenicznych deskach). Według Williama Worthena, w wieku XVII praktyka wystawiania na scenie wcześniej opublikowanych tekstów dramatycznych stanowiła raczej wyjątek i była zarezerwowana dla ściśle określonych gatunków przedstawień (na przykład dramatów religijnych, których przebieg musiał być zgodny z określonym liturgicznym porządkiem) (Worthen 2013: 32). W europejskiej praktyce teatralnej aktorzy zwykle dysponowali bowiem co najwyżej transkrypcjami swoich ról, a nie całymi tekstami, a publikacje sztuk teatralnych przez cały wiek XVII były traktowane jako podrzędne (Worthen 2013: 31). Określenia „scenariusz" w odniesieniu do dawnych włoskich tekstów teatralnych używa się zatem głównie po to, by odróżnić te pisane ,pozostałości” po teatralnej barokowej praktyce scenicznej od historycznie zmiennych retorycznych konwencji gatunku dramatycznego, który ukształtował się później, w połowie XVIII wieku, wraz z rozwojem kapitalistycznego drukarstwa, i by wskazać, że w przeważającej większości owe scenariusze nie zawierały spisanych dialogów postaci, ale jedynie zdawkowe streszczenia fabuł i opisy akcji scenicznej wystawianych w teatrze sztuk. Mówię tu całkiem celowo o pozostałościach, gdyż sama koncepcja dokumentu historycznego lub literackiego zabytku uwikłałaby mnie niechybnie w polemikę o charakterze historyczno-literackim.

Tymczasem problem, któremu chciałabym się przyjrzeć w niniejszym artykule, nie dotyczy samej nieliterackości dawnych tekstów dla teatru, której historycznie zmienne rozumienie (dodatkowo skomplikowane poprzez silnie rozwiniętą w XIX i XX wieku literacką teorię dramatu) ma 
na świecie i w Polsce swoją długą tradycję i zostało już dogłębnie opisane i zbadane ${ }^{1}$. Znacznie ważniejsza od nieliterackości tych tekstów wydaje mi się bowiem ich niedokończoność, fragmentaryczność, rozumiana tutaj bardziej metaforycznie jako - nie zawsze możliwy do zidentyfikowania i zaklasyfikowania - ślad, rodzaj resztki dawnej praktyki teatralnej, której już nie ma lub która odeszła w zapomnienie.

Komedia dell'arte to dawna praktyka włoskiego teatru, która - jak sądzi wielu badaczy - nie tyle zanikła, ile utraciła swoją ciągłość. Nie istnieje już bowiem cały system produkcji teatralnej opartej na przekazywanych z pokolenia na pokolenie kompetencjach konkretnych aktorów, na które składały się znajomość scenariuszy, dialogów, skeczy typowych dla określonych dramaturgicznych rozwiązań i masek (czyli w dużym uproszczeniu mówiąc - występujących na scenie postaci), zaś dla współczesnej publiczności raczej nieczytelny wydaje się dziś kontekst kulturowy, językowy i społeczny tego teatru, który przez ponad dwa stulecia, od połowy XVI do końca XVIII wieku, umożliwiał publiczności odbiór tych przedstawień jako wydarzeń pozostających w ścisłym związku z historycznie zmienną rzeczywistością wielu krajów europejskich. Trudno też na podstawie owych scenariuszy, często rzeczywiście bardzo zdawkowych, wyobrazić sobie sceniczny kształt dawnych przedstawień, bo teksty te nie operują retorycznymi strategiami stwarzania w wyobraźni czytelników fikcyjnych światów, jak czyniły to powieści i wzorowane na nich dramaty w XIX wieku. A jednak raz po raz ktoś zaczyna grać w teatrze komedię dell'arte ${ }^{2}$, internet pełen jest filmowych zapisów ćwiczeń aktorskich z komedii dell'arte, wykonywanych

1 W Polsce dyskusja nad literacką i teatralną tożsamością dramatu toczyła się w zasadzie przez cały okres powojennej teatrologii i została poglądowo ujęta w dwóch tomach pod redakcją Janusza Deglera (Degler 2003). Historycznie ukształtowanej koncepcji nieliterackości scenariuszy komedii dell'arte ja sama poświęciłam szereg rozważań w swojej ostatniej książce (Bal 2017). Tematem literackiej i teatralnej tożsamości dramatu w kontekście rozwoju kapitalistycznego drukarstwa zajmował się też ostatnio William Worthen (Worthen 2005; Worthen 2013).

2 Znakomitym przykładem w tym kontekście jest chociażby przedstawienie Daria Fo Misterium Buffo z 1960 roku, którego nieco późniejszą wersję można oglądać dzisiaj na serwisie YouTube: https://www.youtube.com/results?search_query=mistero+buffo+dario+fo (dostęp: 30.05.2019.). Fragmenty tego przedstawienia, będące poglądową ilustracją sposobów gry aktorskiej w masce, Fo wykorzystał następnie podczas warsztatów Lezioni di teatro w Teatrze Argentina w Rzymie w 1984 roku, które również dostępne są w sieci pod adresem: https://www.youtube.com/watch?v=ADUGqA8dKqk (dostęp: 30.05.2019). 
przez najróżniejszych specjalistów z całego świata ${ }^{3}$; co roku w lutym obchodzi się na świecie tydzień komedii dell'arte, a w Krakowie działa nawet zespół teatralny dell'arte $(!)^{4}$, nie mówiąc o tym, że bibliografia dotycząca tej praktyki teatralnej dorównuje studiom szekspirowskim.

Dlatego tym bardziej intrygujące wydawało mi się zdefiniowanie procesu tłumaczenia tych dawnych tekstów (po które tłumacze sięgają niezwykle rzadko), będących wyrywkowym śladem zapomnianej choć paradoksalnie wciąż odtwarzanej na określonych zasadach praktyki teatralnej. Nie chcę jednak pytać tutaj o praktyczny pożytek takiego przekładu (czyli o to, co dzisiaj współczesny twórca teatralny zrobi z przetłumaczonym przeze mnie tekstem), ale o nowe spojrzenie na pracę i rolę thumacza, która w moim mniemaniu polega na epistemicznym procesie nawiązywania relacji z dawnymi praktykami scenicznymi i szerzej - nawiązywania relacji z czasem minionym w ramach przekładu, który określić chciałabym mianem ,performowania resztek". Termin ten zapożyczyłam od Rebekki Schneider, amerykańskiej badaczki performansu, która wprowadziła go do współczesnej humanistyki w wydanej niespełna dziesięć lat temu monografii Performing Remains. Art and War in Time of Theatrical Reenactment (Schneider 2011). I choć nie zajmowała się w niej przekładem, to jej koncepcja teatralnych rekonstrukcji wydarzeń historycznych oraz artystycznych przetworzeń przedstawień z przeszłości pomoże mi, przy odpowiedniej interpretacji, wesprzeć moje myślenie o akcie przekładu jako epistemologicznym i jednocześnie performatywnym geście uobecniania przeszłości w teraźniejszości.

Ponieważ teoria performansu i performatywności zatacza dzisiaj coraz szersze kręgi, obejmując swym zakresem nie tylko działania o charakterze artystycznym, językowym i społecznym, ale także teorię dyskursu i filozofię nauki (Butler 2008, 2016; Latour 2010, Latour 2014), Rebecca Schneider w swoich rozważaniach musiała odwołać się do takich specyficznych koncepcji performansu, które widzą w nim przede wszystkim narzędzie konstruowania zbiorowej pamięci i wiedzy o przeszłości ${ }^{5}$. Posłużyła się

3 Na przykład warsztaty prowadzone w 2011 roku przez Didi Hopkins w National Theatre w Londynie, https:/www.youtube.com/watch?v=h_0TAXWt8hY (dostęp: 30.05.2019).

${ }^{4}$ Mowa o Studio Dono, atelier teatralnym założonym przez Agnieszkę Cianciarę-Fröhlich i Jonathana Fröhlicha w Krakowie w 2008 roku, http://studiodono.pl (dostęp: 28.09.2018).

5 By wymienić tylko kilku autorów: Nyong'o 2009; Carlson 2000; Connerton 2012; Stoller 2002; Yates 1997. 
więc w punkcie wyjścia zaproponowanym przez Dianę Taylor w jej wpływowej pracy The Archive and Repertuar. Performing Cultural Memory in the Americas (Taylor 2003) ${ }^{6}$ rozróżnieniem dwóch sposobów konstruowania zbiorowej pamięci. Pierwszy z nich, zwany przez Taylor archiwum lub pamięcią archiwalną, ,istnieje w formie map, dokumentów, tekstów literackich, listów, pozostałości archeologicznych, kości, nagrań wideo, filmów, płyt CD" (Taylor 2014: 30), a więc materialnych szczątków przeszłości, które w wyniku umieszczenia ich w archiwum zyskują w zachodniej kulturze status dokumentu lub świadectwa. Na drugi sposób działania pamięci, zwany przez nią pamięcią ucieleśnioną lub repertuarem, „składają się gesty, wypowiedzenia, sposoby poruszania się, taniec, śpiew, czyli wszystkie akty, które zwykle uznaje się za wiedzę ulotną i niemożliwą do zreprodukowania" (Taylor 2014: 30). Taylor dokonała znaczącego rozróżnienia na pamięć archiwalną i ucieleśnioną głównie po to, by wskazać na jego ideologiczne zaplecze. Wychowana w Ameryce Łacińskiej, w Meksyku, doskonale zdawała sobie bowiem sprawę z tego, że kultura zachodnia między innymi dlatego zanegowała część tożsamości kulturowej społeczeństw kolonialnych, gdyż nie pozostawiły one po sobie materialnych, pisanych dokumentów. I że zachodnia wiedza historyczna tylko dlatego prześlepiała przez długie lata cały dorobek kulturowy wspólnot niegdyś skolonizowanych, gdyż ich dziedzictwo i tożsamość kształtowane były w sposób ucieleśniony, performatywny, uważany na Zachodzie za ulotny, bo niedający trwałych materialnych dowodów.

Schneider, podobnie jak Taylor, nie ma oczywiście żadnych wątpliwości co do potrzeby krytyki uprzywilejowanego statusu archiwum w kulturze zachodniej. Podążając bowiem ścieżką myślenia wytyczoną jeszcze przez Michela Foucaulta w Archeologii wiedzy (Foucault 1977) oraz przez Jacques'a Derridę w Gorączce archiwum (Derrida 1995), podkreślała, że ma ono wymiar przede wszystkim polityczny (Schneider 2011: 97). Jak bowiem przypomina Derrida, słowo ,archiwum” pochodzi z języka greckiego i wiąże się z uprzywilejowaną figurą archonta, władcy polis, a więc tego, który posiadał prawo do wytwarzania i reprezentowania prawa" (Schneider 2014: 22; por. Derrida 1995: 2). Za zbiorem materialnych świadectw historycznych (dokumentów pisanych, w tym także literatury i tekstów

${ }^{6}$ Fragment pierwszego rozdziału z tej książki w polskim przekładzie M. Sugiery i M. Borowskiego pod tytułem Archiwum i repertuar. Performanse i performatywność. PerFORwhat studies? opublikowany został w: Taylor 2014. 
rozumianych jako skończone dzieła) stoi zatem zwykle Foucaultowski autorytet dyskursu władzy-wiedzy, określany jako „system wypowiadalności” (Schneider 2014: 22; por. Foucault 1977: 164-165). A ten, jak wiadomo, ma moc nadawania konkretnych znaczeń i kształtowania funkcji archiwalnych zbiorów. Polityczny aspekt archiwum przejawia się też w samej jego niekompletności. Stanowiąc tak zwany kanon kultury, działa często na zasadzie wykluczającej, wtedy na przykład, kiedy „prześlepia” istotną rolę kobiet czy mniejszości etnicznych w kulturze ${ }^{7}$. Do archiwum, jako materialnego zbioru praw, przepisów, dzieł i dowodów przeszłości, trudno zatem podchodzić bezkrytycznie, mając zawsze na uwadze arbitralność metody, za pomocą której takie archiwum powstaje, oraz ideologiczne zaplecze tworzonej na jego podstawie wiedzy.

Niemniej jednak Schneider dostrzega w archiwum także potencjał performatywny i w tym sensie znacząco różni się od Taylor, która uprzywilejowywać chciała jedynie niematerialne i ucieleśnione praktyki kulturowe w sposobie kształtowania pamięci i dziedzictwa kulturowego. Dla Schneider, która podąża tokiem myślenia Derridy, archiwum nie tylko służy porządkowaniu i zarządzaniu wiedzą o przeszłości, ale jest także nastawione na projektowanie przyszłości. Jest rodzajem „uprzywilejowanej topologii”, mówiąc za Derridą, miejscem spotkania z materialnymi resztkami przeszłości, które stanowią zalążki scenariuszy przyszłości (Schneider 2011: 108). By wyjaśnić swój tryb myślenia, Schneider ucieka się do analogii teatralnej. Jak bowiem dzieła dramatyczne poddają się przyszłym scenicznym przetworzeniom i powtórzeniom $\mathrm{w}$ ramach ucieleśnionych praktyk artystycznych, tak i materialne zbiory archiwum stać się mogą przedmiotem przyszłych odtworzeń, rekonstrukcji i powtórzeń. Według Schneider, w myśleniu Derridy zawiera się najistotniejszy dla niej sekret archiwum, a mówiąc ściśle - jego performatywny potencjał przyszłych przekształceń i powtórzeń (Schneider 2011: 108).

${ }^{7}$ Przykładem rewizji owego kanonu, a więc prób jego uzupełniania, na polu badań teatrologicznych były na przykład serie wydawnicze Nowe Historie i Inna Scena wydawane w Instytucie Teatralnym im. Zbigniewa Raszewskiego (Adamiecka-Sitek, Buchwald, Kosiński 2010; Adamiecka-Sitek, Buchwald 2011a; Adamiecka-Sitek, Buchwald 2011b; Adamiecka-Sitek, Buchwald 2012; Adamiecka-Sitek, Buchwald, 2006; Adamiecka-Sitek, Buchwald 2008). Inny przykład to trzytomowa publikacja przygotowana przez badaczy skupionych wokół Katedry Performatyki UJ (Borowski, Sugiera 2012; Sugiera 2014; Baluch 2014). 
I tu dochodzimy do bodaj najważniejszego momentu rozumowania Schneider. Gdyż moment spotkania człowieka z materialnymi resztkami archiwum traktuje ona jako rodzaj szczególnej, empirycznej, performatywnej relacji z wiedzą o przeszłości, od której zależy jej dalsze przekazywanie. Badaczka mówi o tym wprost:

Pomyślmy o tym w ten sposób: te same szczegóły mogą brzmieć, być odczuwalne, wyglądać, pachnieć i smakować zupełnie inaczej w różnych miejscach, czy też być zapośredniczone przez różne media (lub gdy nieprzekazane $\mathrm{w}$ jednym miejscu są przekazywane w innym). Zgodnie z tym rozpoznaniem performans jest trybem każdej architektury dostępu czy środowiska dostępu (performuje się tryb dostępu w archiwum, performuje się tryb dostępu w teatrze, performuje się tryb dostępu na tanecznym parkiecie, performuje się tryb dostępu na polu bitwy (Schneider 2014: 33).

Postrzega zatem moment spotkania z archiwum jako rodzaj ucieleśnionego doświadczenia, performansu na resztkach właśnie, którego przykładem są dla niej zarówno działania na polu sztuki, teatralne przetworzenia dzieł przeszłości, jak i ponowne ucieleśnione odgrywania wydarzeń historycznych, jak choćby praktyki rekonstruktorów historycznych bitew.

By jednak przekonująco wyjaśnić znaczenie performansu jako tego sposobu, który wytwarza rodzaj architektury dostępu do archiwum po to, by nadać mu funkcję i znaczenie w teraźniejszości i przyszłości, Schneider wskazała na konieczność zawieszenia myślenia o efemeryczności performansu (czyli ucieleśnionych praktyk kulturowych i artystycznych zachodzących w określonym miejscu i czasie). W większości teorii performansu, do których się odwołuje, performans rzekomo wyczerpuje swoje działanie w teraźniejszości i w bezpośredniej relacji między twórcą i odbiorcą. Dlatego też Schneider krytycznie ustosunkowała się do tych teoretyczek performansu - jak chociażby Peggy Phelan czy Eriki Fischer-Lichte (Phelan 2003; Fischer-Lichte 2008) - które chcąc usankcjonować jego ontologiczny status efemerydy, precyzyjnie określały jego ramy formalne i strukturalne. Dla nich - badających głównie tak zwane performanse artystyczne, czyli działania artystów polegające na utrzymywaniu widzów w ciągłej niepewności co do przebiegu i czasu trwania przedstawienia i zachęcaniu ich do zamiany ról między twórcą a odbiorcą - warunkiem sine qua non performansu były wymiana i obieg energii między twórcami i widzami we wspólnie podzielanej materialnej przestrzeni w ramach autopojetycznej pętli feedbacku. Taki performans, w ich mniemaniu, nie tylko nie odtwarzał 
niczego wcześniej istniejącego (w przeciwieństwie na przykład do przedstawień teatralnych, które odtwarzały znane wcześniej scenariusze kulturowe, przeszłe wydarzenia lub dzieła literackie), ale także nie pozostawiał po sobie żadnych śladów (gdyż ewentualne zdjęcia lub nagrania takich performansów uniemożliwiały ich zdaniem autopojetyczny obieg energii między twórcą i odbiorcą). Teorie Phelan i Fischer-Lichte zostały jednak szybko podważone, i to nawet nie przez samą Schneider, ale głównie przez badaczy współczesnej kultury medialnej. Philip Auslander na przykład dowiódł, że nowe media, takie jak telewizja czy internet, pokazując świat w zbliżeniu, powiększeniu i w wysokiej definicji dźwięku i obrazu, o wiele skuteczniej produkują w widzach wrażenie bezpośredniości i intymności niż tradycyjne formy podawcze, uważane przez wcześniejszych badaczy za rzekomo niezapośredniczone, takie jak teatr czy sztuka performansu (Auslander 2007). I że tak zwany efekt liveness - po polsku tłumaczony jako „nażywość” (Auslander 2012: 18-27) - który można rozumieć jako wrażenie realności i bezpośredniości doświadczenia - nie ma podstaw ontologicznych, gdyż jest w istocie kategorią historycznie zmienną, zależną od przyzwyczajeń percepcyjnych, rozwoju technologicznego świata i szeregu innych okoliczności.

Zresztą Schneider nie chodziło wcale o przeformułowanie ontologicznego statusu performansu pod kątem jego działania bezpośredniego lub zapośredniczonego przez media lub technologie. Chciała raczej pokazać, na jakich zasadach przedstawienie zmienia nasze myślenie o przeszłości jako o czymś bezpowrotnie minionym oraz jak nadwątla nasz linearny model pojmowania czasu. Dlatego w swoich rozważaniach odwołała się do dwóch przykładów działań performatywnych, które w czytelny dla widza sposób przetwarzały wydarzenia z przeszłości w geście ponownego wykorzystania jej śladów, każąc jednocześnie widzom śledzić sposoby obramowywania przeszłości w teraźniejszości. Przyglądać się więc zaczęła teatralnym odtworzeniom historycznych bitew wojny secesyjnej w Stanach Zjednoczonych (tzw. reenactments) oraz retrospektywnej autorskiej wystawie Mariny Abramović Artystka obecna z 2010 roku w galerii MoMA w Nowym Jorku. W rekonstrukcjach historycznych bitew ciekawił ją zwłaszcza potencjał transmutacyjny owych przedstawień, których twórcy na przykład na południu Stanów Zjednoczonych, dbając z jednej strony drobiazgowo o odtworzenie każdego szczegółu stroju i broni z epoki, a nawet potraw przyrządzanych w przeszłości, z drugiej niejednokrotnie zmieniali wyniki kluczowych dla wojny secesyjnej bitew, chcąc niejako odwrócić jej ostateczny finał lub 
zawrócić bieg historii. Tym samym ich performans, koncentrując uwagę widzów na ujawnionych przeinaczeniach, lukach lub jawnej kreacji minionych wydarzeń, wprost pokazywał performatywny, sprawczy potencjał tkwiący w teatralnych odtworzeniach świadectw historycznych. Jak na dłoni bowiem unaoczniały one widzom ,tu i teraz” gest arbitralnego ustanawiania i konstruowania zbiorowej pamięci o przeszłości.

Z kolei retrospektywna wystawa Mariny Abramović w galerii MoMA w oczach Schneider w zasadzie znosiła zarysowaną wcześniej opozycję pomiędzy archiwum a repertuarem, pokazując, że traktowane do tej pory jako efemeryczne i niemożliwe do „skatalogowania” lub ,zdeponowania” w archiwum działania artystyczne, takie jak performanse, mogą być skutecznie wystawiane w ramach muzealnej wystawy. Odgrywane na oczach widzów przez aktorów dawne performanse Abramović z lat 60. i 70. XX wieku podważały tym samym ontologiczny status archiwum jako zbioru materialnego dziedzictwa kulturowego. Zaś przedmiotem kontemplacji i refleksji widzów czyniły, według Schneider, sam upływ czasu między „tu i teraz” i „tam i wtedy". Widzowie śledzili na bieżąco zarówno zapisy wideo dawnych performansów artystki, jak i odgrywane ich współczesne wersje. Na dodatek Marina Abramović, obecna na wystawie, siedząc godzinami na krześle przez ponad trzy miesiące, dzień w dzień, i dając zwiedzającym sposobność spotkania z nią twarzą w twarz, niejako na własnym ciele sprawdzała „rozciągliwość” teraźniejszości w czasie, a zarazem wytrzymałość swoją i widzów mierzoną posłuszeństwem jej kręgosłupa. Nie mówiąc o tym, że sama poprzez swoją obecność w muzeum ustanawiała rodzaj żywego, cielesnego archiwum własnej twórczości. Zarówno więc rekonstrukcje bitew, jak i retrospektywna wystawa Mariny Abramović, w rozumowaniu Schneider okazały się skutecznym epistemicznym narzędziem rozpoznania relacji między sztuką a upływem czasu. Jak sama pisała:

Jeśli przyjmiemy, że performans nie znika (wbrew temu, co uważali eksperci od archiwów), lecz że jest zarówno aktem pozostawania, jak i medium ponownego pojawiania się i uczestniczenia, niemal natychmiast będziemy musieli przyznać, że resztki to nie tylko dokumenty, obiekty i kości w opozycji do ciała. Tutaj ciało staje się rodzajem archiwum i miejscem pamięci kolektywnej. Pamięć cielesna, odczytywana poprzez genealogię uderzenia i rykoszetu, jest zawsze interaktywna (Schneider 2014: 29-30).

Przeszłość zatem, parafrazując Schneider, pojawia się w teraźniejszości jako rodzaj odtworzonego za pomocą ciała, powtórzonego zachowania, 
odgłosu przeszłości, który równocześnie w pewnym sensie odkłada się w ciałach swoich odbiorców w taki sposób, że stają się oni jej świadkami:

W stopniu, w jakim pozostaje - a zostaje inaczej lub w różnicy - przeszłość performowana i uwyraźniona jako żywy performans, może funkcjonować jako rodzaj transmisji cielesnej, której tak obawiają się konwencjonalni archiwiści, jako przeciwpamięć - niemal w sensie echa. Jeżeli uznamy, że echo lub pogłosy (...) są, tak jak performans, oddźwiękiem przeżywanego doświadczenia, wtedy musimy myśleć poza wzorcem archiwum, który każe nam widzieć performans jako znikający. Stajemy jednocześnie wobec możliwości sformułowania zasad, zgodnie z którymi performans (...) brzmi inaczej, poprzez (...) powtórzenie - brzmi jak echo w uszach powiernika, widza, świadka (Schneider 2014: 34).

Streszczając myśl Schneider, możemy powiedzieć, że taki performans, znowu wbrew zwolennikom jego efemeryczności, pozostawia w nas pewne ślady, choć niekoniecznie w formie materialnej. Istnieją przecież takie formy dowiadywania się o przeszłości lub jej pamiętania, które mają na przykład charakter afektywny lub sensoryczny, jako zachowana w ciele, choć mentalnie wyparta trauma, która skutkuje świadomym prześlepianiem pewnych zdarzeń lub, odwrotnie, nadwrażliwością na niektóre typy doświadczeń. Ów specyficzny czas performansu jest zatem „opóźnionym bitem przeszłości w teraźniejszości”, jak mówi Schneider, rodzajem synkopowego uderzenia czasu (syncopated time), w którym dokonuje się konkurencyjne wobec logiki archiwum ustanawianie pamięci, nie poprzez jej namacalne i materialne świadectwa, które wskazują na coś bezpowrotnie straconego „za nami”, ale poprzez ucieleśnioną praktykę i działanie, które stanowią ich powtórzenie, przetworzenie i uobecnienie w teraźniejszości. Podsumowując myśl Schneider, można zatem powiedzieć, że pamięć kulturowa w rzeczywistości konstruuje się w stałym napięciu pomiędzy repertuarem i archiwum, w serii różnorodnych wzajemnych odtworzeń i przekształceń, które wciąż na nowo modelują nasze wyobrażenia o przeszłości, z jednej strony poprzez różnorodne sposoby „używania” jej resztek, a z drugiej poprzez nowe sposoby archiwizowania naszych kulturowych doświadczeń, jak choćby w chwili, kiedy muzea, zamiast wystawiać dawne narzędzia i eksponaty, uczą zwiedzających na warsztatach różnych dawnych praktyk rzemieślniczych.

By więc lepiej zrozumieć działanie proponowanej przez Schneider metody w odniesieniu do wywołanego na wstępie przykładu strategii nawiązywania relacji z dawną praktyką włoskiego teatru, wystarczy odnieść się 
do takich przedstawień teatralnych, które w często trudny do zrozumienia dla samych twórców sposób wskrzesiły w opinii widzów i badaczy dawną praktykę teatralną. Wymownym przykładem wydaje mi się w tym kontekście przedstawienie Giorgio Strehlera Arlecchino servitore dei due padroni, grane nieprzerwanie na scenie Teatro Piccolo di Milano od blisko 70 lat. Mówiąc o tym właśnie przedstawieniu, Allardyce Nicoll, historyk włoskiej tradycji teatralnej, twierdził w latach 60 . XX z przekonaniem, że ,próbie rekonstrukcji obrazu tego, co ongiś reprezentowała komedia dell'arte, brakowałoby wiele, gdyby nie możliwość oglądania Marcella Morettiego jako Arlekina (...) w pelnej życia realizacji (podkreślenie autorki) Arlecchino servitore dei due padroni przez Piccolo Teatro della Città di Milano" (Nicoll 1967: 6). A przecież to wyobrażenie brytyjskiego badacza o „żywotności” dawnej praktyki scenicznej opierało się na zasadniczym paradoksie, który ujawnił już sam Strehler, reżyser przedstawienia, w swoim zbiorze tekstów O teatr dla ludzi (Strehler 1967; pol. 1982: 199-207). Pisał całkiem wyraźnie, że jego inscenizacja sztuki Goldoniego była raczej od początku do końca eksperymentem, gdyż żaden z aktorów Teatro Piccolo nie dysponował w 1947 roku (czasie premiery pierwszej wersji tego przedstawienia) tymi umiejętnościami, którymi posługiwali się włoscy aktorzy przed trzystu laty zarówno na Półwyspie Apenińskim, jak i poza jego granicami ${ }^{8}$. Do lamusa odszedł już bowiem zarówno typ produkcji przedstawień opartych na scenariuszach i improwizacyjnej grze aktorów, jak i model transmisji rzemiosła aktorskiego, w ramach którego zawodu uczono się w zespołach - rodzinach, gdzie młodsze pokolenie obserwowało rodziców podczas pracy na scenie. Zatarły się także w pamięci widzów niuanse dotyczące samych masek komedii dell'arte, ich kulturowych kontekstów oraz faktycznej roli, jaką pełniły w ramach przedstawień włoskich artystów. Dlatego w jednej z późniejszych wersji tego przedstawienia Strehler ujął sceniczną akcję sztuki w kognitywną ramę teatralnej próby, każąc swoim aktorom mierzyć się na oczach widzów $\mathrm{z}$ dawnym tekstem. Dobitnie w ten sposób pokazał dystans dzielący nasze

${ }^{8}$ Można dodać, że charakterystyczny, noszony przez aktora Marcella Morettiego przylegający do ciała strój Arlekina, złożony z pozszywanych ze sobą kolorowych rombów, czarna maska zakrywająca połowę twarzy, półokrągły kapelusik, specyficzny sposób poruszania się aktora na wychylonych nieco na zewnątrz nogach stały się powszechnie rozpoznawalnymi atrybutami tej maski. I choć Arlekin, tak jak go przedstawiali Moretti, a potem Ferruccio Soleri na scenie, popisywał się gagami i akrobatyczną sprawnością, to pewnie bliżej mu było do cyrkowych klownów lub aktorów kina niemego, chociażby Charliego Chaplina, niż do XVIII-wiecznych masek $\mathrm{z}$ historii teatru. 
dzisiejsze doświadczenie od dawnej praktyki teatralnej i ujawnił gest jej zawłaszczenia lub przetworzenia we współczesnej inscenizacji.

Trzeba też dodać, że świadomie zmienił tytuł komedii Goldoniego ze Stugi dwóch panów na Arlekina, stugę dwóch panów, gdyż - jak mniemałimięjednej z komediowych masek pozwoliłoby widzom łatwiej skojarzyć to przedstawienie właśnie z komedią dell'arte. I zrobił tak, pomijając zupełnie fakt, że dla Goldoniego (autora sztuki) w połowie XVIII wieku maska Arlekina stanowiła już tylko niewygodny balast pewnego etapu włoskiej praktyki scenicznej, gdzie cały ciężar spektaklu spoczywał zwykle na brawurze jednego aktora, podczas gdy on sam, wzorując się na oświeceniowych autorach francuskich, dążył raczej do przekształcenia swoich komedii w dramaty mieszczańskie, z których stopniowo usuwał stare i zgrane w jego mniemaniu maski komediowe. Poza tym, na scenach teatralnych XVIII-wiecznej Italii maska Arlekina nie była wcale popularna na terenie całego terytorium Włoch. Zdaniem włoskich historyków teatru, między innymi Delii Gambelli i Ferdinanda Tavianiego, z Arlekinem wiąże się bowiem pewien paradoks (Gambelli 1972; Taviani, Schino 1982). Choć przypisywano mu na scenie bergamoński rodowód (od miasta Bergamo we Włoszech), maska ta ukształtowała się i po raz pierwszy pojawiła na scenie teatralnej we Francji, dokładnie w Paryżu pod koniec XVI wieku. Przez długie też lata aktorzy włoscy nie eksploatowali jej na rodzimych scenach, zaczęli się nią posługiwać dopiero pod koniec wieku XVII, a tak naprawdę jedynie we wczesnych sztukach Goldoniego. Arlekin przywędrował więc do Włoch, jak sugerują włoscy badacze, dopiero w wyniku wielkiej popularności konkretnych aktorów, którzy zakładali jego maskę na scenie w stolicy Francji w XVII wieku, takich jak Tristano Martinelli, a zwłaszcza Domenico Biancolelli i Evaristo Gherardi, i dzięki fascynacji, jaką później w XVIII wieku rozbudziła we Włoszech i w całej Europie oświeceniowa kultura francuska. Strehler dokonał zatem spekulatywnego gestu przesunięcia uwagi widzów z oryginalnego tekstu Goldoniego na maskę teatralną i przywołując w tytule swojego spektaklu Arlekina, jako utwierdzoną w wyobraźni europejskiej ikonę włoskiego teatru, potraktował Goldoniego i jego sztukę nie tyle jako świadectwo końca pewnego etapu włoskiej praktyki dell’arte, ile właśnie jako jej najbardziej modelowy przykład. Praktyki rekonstrukcyjne, odtworzeniowe, jak zatem widać z powyższego przykładu, unaoczniając gest powtórzenia i przetworzenia archiwum, paradoksalnie w oczach widzów uwiarygadniają w synkopowym czasie obecność przeszłości w teraźniejszości. 
By zatem przenieść skutecznie metodologię zaproponowaną przez Schneider na grunt refleksji przekładoznawczej, należy moim zdaniem spojrzeć na pracę tłumacza dawnych tekstów teatralnych analogicznie jak na pracę twórców performansu, którzy biorąc na warsztat jakiś ślad przeszłości, nie pozbywają się wcale licznych wątpliwości i wahań dotyczących tego materiału, nie rezygnują ze spekulatywnych założeń co do jego sensów ani z możliwości jego transmutacji. Sens tej metody polega bowiem, moim zdaniem, na zasadniczym ujawnieniu fragmentaryczności naszej wiedzy o przeszłości oraz specyficznego usytuowania tłumacza w konkretnym ciele, miejscu i czasie, które znacząco wpływa na kształt budowanej przez niego architektury dostępu do przeszłości. I by poglądowo pokazać pożytki płynące z mojego gestu przeniesienia teorii performansu na grunt przekładoznawstwa, zamierzam odwołać się do przykładu XVIII-wiecznego francuskiego tekstu Thomasa-Simona Guellette'a, który jest tłumaczeniem raptularza włoskiego aktora komedii dell’arte, Arlekina - Domenica Biancolellego. Ten ostatni pracował w Paryżu w Comédie Italienne niecałe sto lat przed tym, nim francuski tłumacz wziął na warsztat jego zapiski.

Na wstępie odtworzyć jednak muszę samą historię powstania i współczesnego wydania tego tłumaczenia, które ukazało się drukiem w 1997 roku w wydawnictwie Bulzoni w Rzymie, pod tytułem Arlecchino a Parigi. Lo Scenario di Domenico Biancolelli w redakcji Delii Gambelli (Gambelli 1997a, 1997b). Jak podaje włoska badaczka w swoim obszernym historycznym wstępie do filologicznego wydania manuskryptu Guellette’a, włoskim autorem Scenario był jeden z najsłynniejszych wykonawców maski Arlecchina okresu baroku we Francji (Gambelli 1993: 298). Tytuł zbioru - Scenario - choć brzmi jak znany współcześnie termin „,scenariusz” - w istocie należy rozumieć jako transkrypcję scenicznych działań aktora w ponad osiemdziesięciu komediach, w których zagrał on w szczytowym okresie kariery scenicznej od 1667 do około 1680 roku$^{9}$. Co dla nas, jako czytelników, najważniejsze, Biancolelli nie troszczył się w nim wcale o całościowe odtworzenie przedstawienia, ale opisywał jedynie swój osobisty wkład w rozwój akcji scenicznej. Na podstawie tego zapisu może i udałoby nam się wydedukować typ scenicznej intrygi, ale jeśli chodzi o całą fabułę komedii - musimy zadowolić się jej oglądem wyłącznie z jednego punktu widzenia - aktora grającego określoną postać. Dla Gambelli owa jednostronność

${ }^{9} \mathrm{Na}$ temat różnych hipotez dotyczących okresu, który obejmują zapiski Domenica Biancolellego, zob. Gambelli 1997a : 21-34). 
spojrzenia Domenica Biancolellego (zapis jego własnych działań na scenie) stanowi namacalny dowód na rzecz obalenia pokutującego przez lata przeświadczenia badaczy o improwizacyjnym charakterze włoskich przedstawień okresu renesansu i baroku; improwizacji rozumianej jako kreacyjne i spontaniczne działanie na scenie (Gambelli 1993: 330). Podczas gdy dla mnie kwestią kluczową pozostaje raczej szczątkowość owego zapisu, notatki aktora były przecież jawnie i zamierzenie wycinkowym śladem dawnej scenicznej praktyki, czyli rodzajem resztki, której performatywny potencjał uwolnić mogło jedynie ich ponowne opracowanie lub transmutacyjne powtórzenie, na przykład w geście translacji. Możemy zatem wyobrazić sobie, że sam tekst Biancolellego - który znamy dziś jedynie z francuskiego thumaczenia, gdyż oryginał zaginął - stanowił dla tłumacza Guellette'a duże wyzwanie, gdyż skłaniał raczej do szeregu spekulacji i chwiejnych założeń, niż konstruowania jakiejkolwiek ,twardej” wiedzy lub wizji przeszłości.

$\mathrm{Na}$ dodatek kiedy Thomas-Simon Guellette dostał do rąk scenariusz Biancolellego, co mogło stać się około 1734 roku, jak twierdzi Gambelli (Gambelli 1997a: 20), w stolicy Francji działał już tak zwany Le Nouvaux Théâtre Italien, czyli Nowy Teatr Włoski, otwarty w 1717 roku, którego nazwę stworzono po to między innymi, by odróżnić tę scenę od tak zwanego L’Ancien Théâtre Italien, czyli włoskiego teatru działającego w Paryżu w poprzednim stuleciu. Został on zamknięty w 1694 roku przez Króla Słońce w atmosferze obyczajowego skandalu, a jego aktorzy musieli opuścić terytorium Francji (Gambelli 1993: 281-285; Ferrone 2014: 194-195). Jak więc rozumiem, istniała w percepcji widzów wyraźna różnica pomiędzy „dawną” (XVII-wieczną - francuskie l'ancien) a ,aktualną” (XVIII-wieczną, nową francuskie le nouvaux ) praktyką włoskich aktorów, widoczna chociażby w tym, że w składzie zespołu pojawili się zupełnie nowi aktorzy, inaczej grający i - co ważniejsze - podobnie jak paryska publiczność, niepamiętający już przedstawień aktorów z poprzedniego stulecia ${ }^{10}$. Wydaje mi się to o tyle istotne, że analizując przekład Guellette'aa, chciałabym wskazać, jak upływ czasu staje się przeszkodą a jednocześnie powodem ujawnionych w określony sposób jego zmagań z oryginałem.

Guellette, otrzymawszy rękopis, sporządził na jego podstawie w roku 1750 francuskie tłumaczenie, uzupełnione o szereg kwerend i objaśnień historycznych, które następnie opublikował w wydawnictwie braci Parfaict

${ }^{10}$ Na temat performatywnych konsekwencji upływu czasu między kolejnymi występami włoskich artystów na paryskiej scenie w XVII i XVIII wieku zob.: Bal 2017: 103-110. 
w Paryżu w 1753 roku (Gambelli 1993: 298). Jak się wydaje, nie był zadowolony z efektu swojej pracy, gdyż, jak podaje Gambelli, pracował dalej nad manuskryptem, czyniąc na nim kolejne adnotacje i nanosząc komentarze, w zasadzie prawie aż do śmierci w 1766 roku (Gambelli 1993: 299). I tę ostatnią wersję tłumaczenia Guellette'a, z jego notatkami, uwagami, poprawkami, pytajnikami, skreśleniami, czytać dziś możemy w transkrypcji i opracowaniu Delii Gambelli.

W tej edycji moją uwagę zwrócił przede wszystkim sposób, w jaki Guellette ujawniał w rękopisie swoje wahania, niepewny stosunek do treści przedstawianych przez autora oryginału, a także najczęściej swoją bezradność wobec niemożności rozszyfrowania wyjściowego tekstu i zrozumienia jego wewnętrznych sprzeczności. Guellette zaznacza na przykład na marginesach swojego manuskryptu, że musiał niektóre fragmenty oryginału wyciąć, gdyż wydawały mu się one niezrozumiałe albo niepotrzebne. Prowadzi też swoisty dialog z Biancolellim, na przykład notując na marginesach swoje zdziwienie tym, że włoski aktor mógł używać na scenie tak obscenicznych słów jak cagare (włoskie „srać”), i uczciwie zaznacza, że zastąpił je bardziej przyzwoitym francuskim me mettre à mon aize (ulżyć sobie). Wreszcie tam, gdzie komiczna gra słów nie pozwala na zadowalający go przekład francuski, pozostawia w nawiasach wyrażenia włoskie ${ }^{11}$. Krótko mówiąc, daje do oglądania cały swój warsztat tłumacza wraz z jego ograniczeniami, wadząc się i dyskutując z oryginalnym tekstem, co daje efekt dziwnego dwugłosu: czytelnik słyszy głos Dominiqua Biancolellego, który w pierwszej osobie streszcza swoje działania sceniczne $\mathrm{i}$ interakcje $\mathrm{z}$ towarzyszącymi mu postaciami, jednak raz po raz w słowo wchodzi mu Guellette, który w nawiasach, w przypisach lub na marginesie komentuje i dopowiada to, co budzi jego

${ }^{11}$ W jednej ze wczesnych komedii Baron Tedesco (Niemiecki baron) widać chociażby, jak w nawiasach Guellette wyjaśnia dowcip słowny i nie mogąc znaleźć dla niego skutecznego odpowiednika po francusku, zostawia w nawiasie włoskie wyrażenie (tłumaczenie własne):

„Pojawiam się na scenie śmiesznie przebrany za niemieckiego barona. Trivellino zjawia się na scenie i powtarza mi , że dał mi ten strój tylko po to, żeby wykręcić pewien numer. Podczas gdy próbuje mi wyjaśnić, o co się rozchodzi, ja ściągam z siebie wszystkie ubrania i uciekam. On goni za mną, łapie mnie, przyprowadza z powrotem, a ja mówię mu «Chcesz, żebym przez ten numer trafił do więzienia?», ale on mnie pociesza i mówi, że muszę udawać niemieckiego barona. Dlatego pyta mnie, czy nie znam jakichś innych języków poza swoim własnym, a ja odpowiadam, że znam ich całe mnóstwo. Na co on pyta, czy znam niemiecki (si je sai parler allemand, przyp. Guellette), co ja rozumiem opacznie, jako «czy umiem mówić rękami» (włoskie alle mani, przyp. Guellette). «I to jeszcze jak!» - odpowiadam «Rękami i nogami!» (Gambelli 1997a: 178-179). 
wątpliwości w sformułowaniach Włocha. I by poglądowo pokazać, jak funkcjonują te wtrącenia, zmuszona jestem skopiować tutaj nieco dłuższy fragment jednej z pierwszych sztuk streszczonych w zbiorze, La double jalouzie (wł. „Le doppie gelosie”, pol. „Podwójna zazdrość”), w którym ujęte w nawiasy wtrącenia Guellette'a zaznaczyłam kursywą.

Acteurs :

La Double Jalouzie

Le doppie gelosie

Arlequin

$1^{\text {ere }}$ Amoureuze

Pantalon

$2^{\mathrm{e}}$ Amoureuze

Le Capitan

$2^{\mathrm{e}}$ Amoureux

$1^{\circ}$ Zani

Octave

La Soubrette

\section{Act $1{ }^{\text {er }}$}

Je sors avec Octave qui fait un monologue dans lequel il donne à entendre qu'il est tres agité, je luy dis „Mon cher maistre, vous estes melancolique, vous n'avez pas de confiance en moy. Vous sçavez pourtant que c'est sur les plaines les plus hauttes que l'on pesche le corail, que c'est dans la mer la plus profonde que l'on trouve les mines de diamans, que c'est dans les foureaux les moins ornez que l'on voit souvent les meilleurs lames; imaginez-vous donc que je suis ce foureau où il y a une bonne espée pour vous servir. Est'ce que vous craignez que le peuple d'Israël (les fripiers) ne viennent vous reprendre ces habits?". Octave soupire...., ,Resouvenez-vous - luy dis-je - que le bon vallet est le principal membre de son maistre...” „Ah, Arlequin, - me/respond Octave - je suis amoureux!...”, „Et bien, je le suis aussy. Est-ce que vostre maistress seroit une Lucresse?..." alors je luy dis ce qui me vient de fantazie.

Arrive sa maistress (ce devoit estre Euralia), il est estonné, je prens la parolle et je luy fais un compliment pour mon maistre et luy demande excuze de sa betize (Gambelli 1997a: 97-98) ${ }^{12}$.

12 Dla czytelników nieznających włoskiego podaję własny polski przekład tej sceny:

Podwójna zazdrość

Le doppie gelosie

Aktorzy:

Arlekin

Pierwsza Zakochana 
Ponieważ, jak mówiłam wcześniej, Biancolelli streszczał akcję wyłącznie ze swojej perspektywy i nie pisał dla szerokiego grona czytelników, tylko raczej dla siebie, często omijał imiona postaci, nazywając je zgodnie z pełnioną funkcją w sztuce (np. kochanką). Zaniepokojony Guellette w nawiasach snuje swoje domysły, kim może być owa kochanka, o której wspomina Arlekin, więc w nawiasie dodaje (to powinna być Euralia). Wcześniej też, nie licząc na przenikliwość Francuzów, odnośnie wyrażenia le peuple d'Israël dodaje w nawiasie bardziej swojsko brzmiące (les fripiers), czyli „obwoźni handlarze ubraniami”. Ale jego dywagacje bywają też o wiele bardziej rozbudowane. W jednym z przypisów w tej samej sztuce zastanawia się na przykład, kim może być postać określana przez Biancolellego jako „Pierwszy Zanni” i który z aktorów mógł wcielać tę maskę na scenie sto lat wcześniej. Niepewny swoich domysłów, przyznaje się do podjęcia arbitralnej decyzji i zastąpienia owego Pierwszego Zanniego imieniem Trivellina, bo „tak mu pasuje” w tej scenie. Zacytuję tu najpierw fragment komedii, do którego odnosi się przypis, a następnie brzmienie samego przypisu Guelletta, zaznaczonego kursywą:

Cette scene se passe dans la nuit; je dis à mon maistre qu'il ne faut pas qu'il compte sur moy, parce que je suis tres poltron, il veut aller à la porte du jardin

Pantalone

Druga Zakochana

Kapitano

Drugi Zakochany

Pierwszy Zanni

Oktawio

Subretka

Wchodzę na scenę razem z Oktawiem, który wygłasza monolog. Daje w nim do zrozumienia, że jest bardzo zaniepokojony. Na to ja mówię mu: „Mój panie, jest pan melancholikiem. I na dodatek nie ufa mi pan. Powszechnie wiadomo, że korale łowimy zawsze na najwyższych szczytach, kopalnie diamentów znajdują się w najdalszych głębinach morskich, a w najmniej ozdobnych pochwach kryją się najostrzejsze miecze. Niech pan sobie wyobrazi teraz, że jestem taką pochwą, w której kryje się ostry miecz, po który wystarczy sięgnąć. Czyżby obawiał się pan, że Izraelczycy (obwoźni handlarze) zedrą z pana ten rynsztunek?’. Oktawio wzdycha. „Niech pan pamięta - mówię mu - że dobry sługa jest najsprawniejszym członkiem pana...” „Ach, Arlekinie - odpowiada mi Oktawio - zakochałem się!....”, „To wspaniale, ja też. Czy pana wybranką jest może Lukrecja?...” Po czym plotę, co mi ślina na język przyniesie.

Wchodzi jego wybranka (to powinna być Euralia), Oktawio jest zaskoczony, biorę sprawy w swoje ręce i przekazuję dziewczynie kilka ciepłych słów na temat mojego pana i przepraszam za jego głupotę. 
et m'ordonne de le suivre; j'entands du bruit, la frayeur me saisit, c'est Trivelin qui, me prenant pour son maistre, me domande si je veux venir souper, je luy reponds: «De tout mon cœur »; nous faison une scene de nuit, mon chapeau tombe, je fais de lazzis / pour le retrouver avec ma batte, je passe entre les jambes de Trivelin; en me levant, je le fais tomber, et apres plusieurs lazzis, je me retire. (...)

Dans le manuscript italien, le nom de Trivelin n-est pas employé que dans

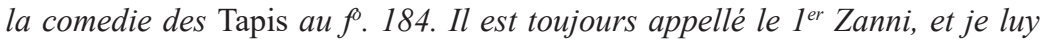
ay donné le nom de Trivelin pour l'intelligence de la scene. Mais qui estoit ce

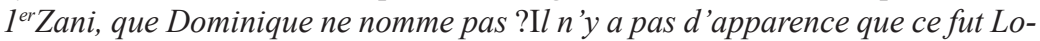
catelli, qui cependant portoit ce nom, comme je l'ay dit cy-devant. Si ce n'est pas luy, comment Dominique jusqu'en 1671, que Locatelli mourut, jouoit'il la comedie? Il n'est pas probable qu'il fust inutile dans la trouppe pendant onze ans, il n'a jamais joüé sans masque, ainsy il falloit qu'il parust sous celui d'Arlequin, Je n'ay trouvé personne qui pu me tirer cela au clair. Le nom d'Aurelia et de Diamantine ne sont non plus employez dans ce canevas, mais seulement $1^{a}$ et $2^{a}$ Donna et La Serva, auxquels j'ai substitué les autres cy-dessus, ainsy que ceux d'Octave et de Cinthio (Gambelli 1997a: 100-101) ${ }^{13}$.

Guellette, co widać na powyższym przykładzie, podstawia postaciom adekwatne jego zdaniem imiona, konfrontuje swoje decyzje ze znajomością składu aktorskiego teatru włoskiego sprzed stu lat, choć nie ma pewności, kto faktycznie mógł grać poszczególne role. I, pomimo że sam był

13 Dla czytelników nieznających włoskiego podaję własny przekład tego fragmentu:

Ta scena rozgrywa się w nocy; mówię mojemu panu, że nie powinien na mnie liczyć, bo jestem zbyt wielkim tchórzem, ale on mimo wszystko chce podejść do drzwi ogrodu i każe mi iść z sobą; słyszę jakiś hałas, oblatuje mnie strach, okazuje się, że to był Trivellino, który wziął mnie za swojego pana. Pyta mnie, czy chcę coś zjeść: „Ależ oczywiście” - odpowiadam; odgrywamy nocną scenę, spada mi kapelusz z głowy, robię różne lazzi, żeby go podnieść za pomocą kija, przechodzę między nogami Trivellina, stając na nogi, trącam go i Trivellino upada, wykonuję jeszcze kilka innych lazzi i schodzę ze sceny (...).

W manuskrypcie włoskim imię Trivellina pojawia się tylko w komedii Tapis (Dywany) na stronie 184. Wszędzie indziej postać ta nazywa się Pierwszym Zannim, ja jednak nadałem jej imię Trivellina, ze względu na logikę tej sceny. Ale kim byt ten Pierwszy Zanni, którego Dominique nie wymienia z imienia? Nie ma żadnych dowodów na to, że to mógt być Locatelli, który w tym czasie grywat tę maskę, jak wspominatem poprzednio. Ale jeśli to nie on, to w jaki sposób Dominique do 1671 roku, kiedy Locatelli umart, grat tę komedię? Przecież to niemożliwe, żeby aktor spędzit bezczynnie $w$ zespole jedenaście lat, nigdy przecież nie grat bez maski, no chyba żeby występowat w masce Arlekina. Nie znalazłem nikogo, kto mógłby rozwiać moje watpliwość. Imion Aurelii i Diamantiny też nie ma w tych scenariuszach, a jedynie określenie Pierwsza i Druga Kobieta oraz Stużąca, które też zastapiłem konkretnymi imionami, podobnie jak w przypadku Oktawia i Cintia (Gambelli 1997a: 100-101). 
autorem komedii dla włoskiej sceny w XVIII wieku, ma spore trudności ze zrozumieniem kontekstów i powodów, dla których Biancolelli pisze tak, a nie inaczej. Pokazuje, jaki jest bezradny, ujawniając te momenty pracy translatorskiej, które zwykle większość tłumaczy, przygotowując tak zwane gotowe przekłady, ukrywa przed czytelnikiem. Myślę tu nie tylko o strategicznych decyzjach dotyczących tego, jaki na przykład sposób mówienia przypisać postaciom w docelowym języku, jakich metafor użyć. Ale również, a może przede wszystkim, jak starannie ukryć swoją niewiedzę, jakie sztuki kamuflażu zastosować, aby skutecznie zasłonić te momenty translatorskiej pracy, w których wyszłoby na jaw, że nasze (nas, tłumaczy) rozumienie tekstu z przeszłości jest pełne luk, błędów, a często opiera się na czystych spekulacjach. Bezradność Guellette'a nie jest przez to dla mnie dowodem ani znakiem porażki tłumacza, ale wręcz przeciwnie. To właśnie ta ujawniona przez tłumacza rama poznawcza staje się paradoksalnie najważniejszym narzędziem performatywnej siły tego przekładu, gdyż ujawnia istnienie zarówno czasu oryginału, istniejącego „tam i wtedy”, jak i teraźniejszości, czasu translatorskiego wysiłku ,tu i teraz”. I ta swoista „uczciwość” Guellette'a co do powziętej metody i własnych kognitywnych ograniczeń jest jednocześnie najbardziej frapująca, otwiera przy tym drogę do szeregu przemyśleń redefiniujących rolę tłumacza.

$\mathrm{Z}$ jednej strony dobitnie pokazuje, że tłumaczenie, które w założeniu funkcjonować ma jako gotowe i pozbawione nieciągłości i wahania dzieło, w rzeczywistości jest efektem szeregu retorycznych strategii, arbitralnie podejmowanych decyzji, czy chociażby przekonania o niemylności tłumacza. Z drugiej, i bodaj ważniejszej, strony tłumaczenie Guellette'a (które pełni tu oczywiście funkcję poglądowego przykładu) stwarza badaczom przekładów i performansów szansę śledzenia procesu, reguł i strategii przejęcia oryginału, będącego jedynie wyrywkowym odpryskiem przeszłości. Staje ono się zatem, analogicznie do performansów oraz rekonstrukcji historycznych u Schneider, epistemicznym narzędziem ujawniania i ustanawiania relacji między różnymi czasami: czasem wysiłku tłumacza i czasem oryginału, teraźniejszością i przeszłością. Takie potraktowanie przekładu przy okazji nobilituje w pewnym sensie wszystkie te niekiedy naiwne (jeśli nie wręcz wyszydzane) dowody bezradności tłumaczy, którzy nie mogąc znaleźć ekwiwalentów słów i sformułowań, opatrują tłumaczone teksty gęstą warstwą przypisów. Oczywiście nie twierdzę tutaj, że wszystkie przypisy tłumacza automatycznie świadczyć muszą o jego skromnej lub ograniczonej wiedzy. Czasem przecież bywa i tak (czego wymownym przykładem są polskie 
edycje dramatów Samuela Becketta w tłumaczeniu Antoniego Libery), że tłumacz daje w przypisach upust całej swojej erudycji i znajomości wszelkich niuansów znaczeniowych oryginału, a przynajmniej skutecznie za pomocą odpowiednich zabiegów retorycznych i edytorskich sprawia wrażenie wszechwiedzy. Jednak nie o erudycję lub niewiedzę tłumacza się tu rozchodzi, ale o dostrzeżenie faktu, że proces thumaczenia ma charakter wyraźnie usytuowany w konkretnym ciele i czasie, który zarówno skutecznie determinuje i określa relacje tłumacza z materialnym śladem przeszłości, jak i wpływa na stwarzany w performatywnym geście obraz tej przeszłości dla potomnych. Taki sposób myślenia o tłumaczeniu zbliża więc refleksję nad przekładem do tych teorii z zakresu filozofii nauki, które nazywa się usytuowaną epistemologią (Braidotti 2013, pol. 2014: 74). Jedna z najbardziej uznanych badaczek tego nurtu, Donna Haraway, w swoim manifeście zatytułowanym Situated Knowledges. The Science Question in Feminism and the Privilege of Partial Perspective, napisanym ponad trzydzieści lat temu (Haraway 1988), przekonująco udowodniła, w jaki sposób współczesna wiedza i tak zwany obiektywizm naukowy są jedynie rodzajem wytwarzanej za pomocą zabiegów retorycznych regulatywnej fikcji, która w rzeczywistości odzwierciedla władczy i promieniujący znikąd model patriarchalnego spojrzenia. Dlatego też zaproponowała, by naukowcy, biorąc pod uwagę określające ich zanurzenie w konkretnej płci, rasie i klasie, zaczęli ponosić bezpośrednią odpowiedzialność za wytwarzaną przez siebie wiedzę, i zaczęła się od nich domagać możliwości uwzględnienia takiego sposobu oglądu rzeczywistości, który byłby wyraźnie usytuowany i lokalny - ograniczony do określonej ucieleśnionej perspektywy widzenia. Efektem zaś tak wytwarzanej wiedzy miało być stworzenie wielu wiedz usytuowanych, które można by z sobą zestawiać i porównywać. Praca tłumacza, rozumiana przeze mnie jako performatywny usytuowany w konkretnym ciele i czasie proces, byłaby zatem analogicznie do pracy naukowca epistemicznym narzędziem tworzenia cząstkowej i lokalnej wizji przeszłości na podstawie jej trudnych do zdefiniowania śladów oraz narzędziem ustanawiania relacji z przeszłością w geście jej współczesnego obramowywania. Przeszłość jawi się tu nie jako monolityczne obiektywne „dzieło”, stworzone ręką wszystkowiedzącego, a jednocześnie bezosobowego świadka patrzącego znikąd, ale raczej jako fragmentaryczna jej wizja służąca ukazaniu kognitywnych ograniczeń translatorskiego oka, które paradoksalnie konstruuje pomost między teraźniejszością a przeszłością. 


\section{Bibliografia}

Adamiecka-Sitek A., Buchwald D., Kosiński D. (red.) 2010. Nowe Historie 1. Ustanawianie historii, Warszawa: Instytut Teatralny im. Zbigniewa Raszewskiego.

Adamiecka-Sitek A., Buchwald D. (red.). 2008. Inna scena. Ciało płeć pożądanie, Warszawa: Instytut Teatralny im. Zbigniewa Raszewskiego.

— 2006. Inna scena/kobiety $w$ historii i współczesności teatru polskiego, Warszawa: Instytut Teatralny im. Zbigniewa Raszewskiego.

_ 2011a. Inna scena/Koniec męskości, Warszawa: Instytut Teatralny im. Zbigniewa Raszewskiego.

— 2011b. Nowe Historie 2. Wymowa faktów, Warszawa: Instytut Teatralny im. Zbigniewa Raszewskiego.

2012. Nowe Historie 3. Nowe biografie, Warszawa: Instytut Teatralny im. Zbigniewa Raszewskiego.

Auslander Ph. 2007, Liveness. Performance in a Mediatized Culture. Second Edition, London- New-York: Routledge.

— 2012. Na żywo czy...?, przeł. M. Borowski, M. Sugiera, „Didaskalia”107, s. 18- 27.

Bal E. 2017. Lokalność i mobilność kulturowa teatru. Śladami Arlekina i Pulcinelli, Kraków: Wydawnictwo Uniwersytetu Jagiellońskiego.

Baluch W. (red.) 2014. Polska dramatyczna 3. Antologia, Kraków: Księgarnia Akademicka.

Borowski M., Sugiera M. (red.) 2012. Polska dramatyczna 1. Dramat i dramatyzacja w XX wieku, Kraków: Księgarnia Akademicka.

Braidotti R. 2014. Po człowieku (2013), przeł. J. Bednarek, A. Kowalczyk, Warszawa: Państwowy Instytut Wydawniczy.

Butler J. 2008. Uwikłani w płeć. Feminizm i polityka tożsamości, przeł. K. Krasuska, Warszawa: Wydawnictwo Krytyki Politycznej.

— 2016. Zapiski o performatywnej teorii zgromadzeń, przeł. J. Bednarek, Warszawa: Wydawnictwo Krytyki Politycznej.

Carlson M. 2000. Performing the Past: Living History and Cultural Memory, „Paragrana" 9/2, s. 237-248.

Connerton P. 2012. Jak społeczeństwa pamiętają, przeł. M. Napiórkowski, Warszawa: Wydawnictwo Uniwersytetu Warszawskiego.

Degler J. (red.) 2003. Problemy Teorii Dramatu i Teatru, vol. 2, Wrocław: Wydawnictwo Uniwersytetu Wrocławskiego.

Derrida J. 1995. Archive Fever. A Freudian Impression, Chicago: University of Chicago Press.

Ferrone S. 2014. La Commedia dell'arte. Attrici e attori italiani in Europa (XVI-XVII secolo), Turyn: Giulio Einaudi Editore.

Fischer-Lichte E. 2008. Estetyka performatywności, przeł. M. Borowski, M. Sugiera, Kraków: Księgarnia Akademicka.

Foucault M. 1977. Archeologia wiedzy, przeł. A. Siemek, Warszawa: Państwowy Instytut Wydawniczy. 
Gambelli D. 1972. Arlecchino dalla preistoria a Biancolelli, „Biblioteca Teatrale” n.5, s.17-68.

1993. Arlecchino a Parigi. Dall 'inferno alla corte del Re Sole, Roma: Bulzoni Editore. 1997a, Arlecchino a Parigi. Lo scenario di Domenico Biancolelli. Parte Prima, Roma: Bulzoni Editore 1997.

__ 1997b, Arlecchino a Parigi. Lo scenario di Domenico Biancolelli. Parte Seconda, Roma: Bulzoni Editore.

Haraway D. J. 1988. Situated Knowledges. The Science Question in Feminism and the Privilege of Partial Perspective, „Feminist Studies” 3, s. 575-599.

Latour B. 2010. Nadzieja Pandory. Eseje o rzeczywistości w studiach nad nauka, przeł. K. Abriszewski, A. Derra, M. Smoczyński, M. Wróblewski, M. Zuber, Toruń: Wydawnictwo Naukowe Uniwersytetu Mikołaja Kopernika.

2014. Agency at the Time of the Anthropocene, „New Literary History” 2014 45, s. $1-18$.

Nicoll A. 1967, W świecie Arlekina, przeł. A. Dębnicki, Warszawa: Państwowy Instytut Wydawniczy.

Nyong'o T. 2009. The Ammalgamation Waltz: Race, Performance and the Ruses of Memory, Minneapolis: University of Minnesota Press.

Parfaict, F. et C. 1753, Histoire de L'Ancien Théâtre Italien, depuis son origine en France, jusqu'à sa suppression en l'an 1697, suivie des extraits ou canevas des meilleures pièces italiennes qui n'ont jamais été imprimées, Paris: Lambert.

Phelan P. 2003. Unmarked. The Politics of Performance, London-New-York: Routledge.

Schneider R. 2011. Performing Remains. Art. and War in Time of Theatrical Reenactment, London-New York: Routledge.

2014. Performans pozostaje, przeł. D. Sosnowska, w: Re//Mix: Performans i dokumentacja, D. Sajewska, T. Plata (red.), Warszawa: Wydawnictwo Krytyki Politycznej, s. 20-35.

Stoller A. L. 2002. Colonial Archives and the Arts of Governance, „Archival Science” $2(2 / 2)$, s. $87-109$.

Strehler G. 1982. O teatr dla ludzi, wybór, wstęp noty A. Zieliński, przeł. R. Kłos, M. Olesiuk, A. Zieliński, Warszawa: Wydawnictwa Artystyczne i Filmowe, s. 199-207.

Sugiera M. (red.) 2014. Polska dramatyczna 2. Dramat i dramatyzacje w XVIII i XIX wieku, Kraków: Księgarnia Akademicka.

Taviani F., Schino M. 1982. Il segreto della commedia dell'arte. La memoria delle compagnie italiane del XVI, XVII, XVIII secolo, Florencja: La Casa Usher.

Taylor D. 2003. The Archive and Repertoire. Performing Cultural Memory in the Americas, Durham-London: Duke University Press.

2014. Archiwum i repertuar. Performanse i performatywność. PerFORwhat studies?, przel. M. Borowski, M. Sugiera, „Didaskalia” 120, s. 22-38.

Worthen W. 2005. Print and the Politics of Modern Drama, Cambridge: Cambridge University Press.

2013. Dramat między literatura a przedstawieniem, przeł. M. Sugiera, M. Borowski, Kraków: Księgarnia Akademicka.

Yates F.A. 1997. Sztuka pamięci, przeł. W. Radwański, Warszawa: Państwowy Instytut Wydawniczy. 